\title{
Development and Optimization of Mild Steel Biogas Plant for utilizing Paddy Straw Residue
}

\author{
Jasvarinder Chalotra* and Sarbjit Singh Sooch
}

Department of Renewable Energy Engineering, College of Agricultural Engineering \& Technology, Punjab Agricultural University, Ludhiana- 141004, Punjab, India

*Corresponding author

\section{A B S T R A C T}

\begin{tabular}{|l|}
\hline Ke y w o r d s \\
Paddy straw \\
management, \\
Design of Paddy \\
straw plant made up \\
of M.S Sheet
\end{tabular}

\section{Introduction}

Biogas generation depends on the environmental conditions of region. The best temperature for production of biogas is above $25^{\circ} \mathrm{C}$ and this temperature is available for 9 months in northern India. Biogas is purely a clean and natural gas and it depends on the anaerobic digestion for production. No interference of human is required for its generation. The only work required for researchers is to develop a system according to biomass available. The new energy generating systems are much needed with the growing concern for country's energy security. Due to escalating cost of petrol and diesel, Bio-energy is gaining importance in such a populated Indian community. 
Paddy straw is available at huge amount in India 43 million cultivated hectares yielding 746 million tons of grains. India occupies the world's largest area under rice grown under a wide range of agro-ecological area. The grain to straw ratio varies from 1:1.3 to $1: 3$.

The percentage of rice in paddy varies from $65 \%$ to $72 \%$ and bran is $15 \%$ to $20 \%$ [1]. It can be utilizes into biogas and electricity generation. Already the biogas plants available in India where cow dung is used as a feeding material. One of the methods for disposal of this paddy straw crop is anaerobic digestion by dry fermentation for production of biogas. This is recently tried in USA.

The method of dry fermentation refers to anaerobic methane fermentation where there is no free or drainable water in crop residues. By utilization of this crop residue a huge amount of energy is captured for power generation and has dual climatic effect too. Firstly it reduces the $\mathrm{Co}_{2}$ - emission through a reduction of the demand for fossil fuel. Secondly important greenhouse gas is reduced.

Anaerobic digestion of crop waste cannot be done by conventional anaerobic process for biogas production because of floating characteristics of paddy straw in water. New process of anaerobic digestion has to be followed with small quantity of water to avoid floating of paddy straw. This process is known as dry fermentation. Therefore batch reactors are required for a dry system, as compared to continuous methods. This is primarily related to field collection, transport and storage methods for crop and crop residues. Loading of batch reactor will be assumed to minimize labour requirements and residue pretreatment needs.

Grewal et al.,[2] explained that the whole system in which anaerobic fermentation of cellulose containing organic material takes place and produce biogas, which accumulates in gas holder or the dome, then utilization of this gas through the gas pipeline under suitable pressure is called biogas plant system. Initially cow dung was mainly used as fermentable material for biogas production of biogas. Jewel W J et al.,[3] explained that in a batch operation, the raw material which mostly consists of farm waste are loaded in the digester, preferably by chafing so as to increase the surface area. It has a fixed cover and the gas produced is stored in a separate gasholder kept flowing over water.

All crop residues like paddy straw, wheat, potato, tendrils, vegetable plants and tree leaves are burnt to clean the field. These crop wastes can be valuable fuel for kitchen and power generation.[4]Anaerobic Digestion (AD) is a most cost-effective bioconversion technology worldwide for commercial production of electricity, heat, and compressed natural gas $(\mathrm{CNG})$ from organic materials [5].

AD produces biogas including methane by utilizing various bacteria's and creates an alternative source of energy. The AD waste and residues from agriculture, industry, municipal organic, and sewage sludge has become one of the most attractive renewable energy pathway [6].

In addition to economic benefits from energy and fuel generation, plants provide additional environmental benefits (e.g. reduction in water, soil, and air pollution). Due to numerous benefits of bio energy, large and intermediate scale biogas projects has become an important type of renewable energy. These projects made a crucial contribution to ecological, economic and social development.

In the background of work, various designs and attempts were made for producing biogas and electricity. Batch flow, continuous flow, continuously expanding, plug flow and contact 
flow are the various digesters developed in past decades [7]. Mostly the cattle dung mixed with water is used for producing biogas and this is common practice in villages of India.

Attempts are made to produce biogas in the metal digester (2feetx 4 feet) with multiple feedstock's, for example, kitchen waste, poultry dropping, cow dung, the average volume obtained in 3months was $1.016 \mathrm{~m}^{3}, 2.489 \mathrm{~m}^{3}, 2.397 \mathrm{~m}^{3}[8]$.

Municipal waste and kitchen waste are used for biogas production in this investigation.

The mathematical modeling of fixed dome digester with the capacity 1 to $10 \mathrm{~m} 3 /$ day was performed and diameter, height, active slurry volume, gas storage volume, gas yield, the pressure of gas, stress pattern of digester were calculated using the developed mathematical model by scaling- up to lab scale data [9].

Water hyacinth is used for biogas production in batch type digester [10].In this attempt agriculture waste and zoo technical waste is used in a batch type digester to produce biogas [11].

Researchers used some selective micronutrients to increase the biogas production in batch type digester [12]. The Paddy straw biogas plant is a batch type system that was developed to utilize paddy straw for biogas production (BP). The plant was tested in Punjab Agricultural University; Ludhiana (India).

\section{Research task and objective}

The main objective of this research was to develop a domestic paddy straw biogas plant as an alternative of LPG cylinders by utilizing waste paddy straw crop residue.

To develop a leakage proof batch reactor required for dry fermentation of crop residues.

\section{Research gap}

Least work done in past years for producing biogas from paddy straw.

No work is done to utilize the paddy straw crop residue for family usage in the form of cooking gas.

Least research work is done in the past for fabricating and designing a big size digester for paddy straw crop residue utilization.

\section{Materials and Methods}

This paddy straw plant was developed on the ground using a cylindrical geometry is tested at Punjab Agricultural University, Punjab (India). The material used to make the plant was mild steel. The temperature in summer in North region of India is always above 40 degrees that gave great benefit as the mild steel plant directly came in the contact of sunlight which helped to increase the biogas production.

\section{Feeding material arrangement}

Paddy Straw (PS) was collected from the fields of PAU, Ludhiana. The required quantity of feeding material was collected, chopped and stored. $200 \mathrm{~kg}$ of fresh cow dung was used during the feeding process from the Dairy Farming Department, PAU Ludhiana. Table.1 shows the composition for biogas production $(\mathrm{BP})$

\section{Paddy straw mild steel digester}

In this research, newly developed design based on PS biogas generation is developed and manufactured. The digester was tested for three months in an open field standing on the ground, which remained in contact with sunrays all the time. The storage capacity is $600 \mathrm{~kg}$. MS sheet of 10 gauges was used for manufacturing. The plant has a manhole on 
the top from where the paddy straw was loaded. The dimension of plant is 3 feet in diameter with two parts, in the form of a ring, first is permanently fixed with an upper sheet and second is flexible. A high-temperature resistant seal was inserted between these two rings to avoid leakage. These rings were tightened by bolts. Three 5 feet Girders were welded with digester as a stand. The auto CAD drawing of the plant is shown in fig.1. The fabricated digester as per drawing is shown in fig.2. Complex biogas production and paddy straw management system was developed to produce energy. The main focus is to develop an eco-friendly system which is beneficial for family and country.

\section{Batch operation}

Initially the mild steel PS digester was filled with four layers of paddy straw and cow dung. The first layer consisted $120 \mathrm{~kg}$ of paddy straw and $30 \mathrm{~kg}$ of the cow dung above it. Similarly, rests of three layers were filled. A total $460 \mathrm{~kg}$ paddy straw was mixed with 150 $\mathrm{kg}$ cow dung for batch production. After that, water was mixed for 10-15 minutes. The supply of biogas was attached with stove. Initially no pressure and fire flames were found. On $7^{\text {th }}$ day, digester started producing biogas. When stove ignited, fire flames appeared that was ready to use for cooking. The gas produced in continuous manner i.e. once started continues to produce. The material that was used as feeding automatically converted into bio-digested slurry that can be used in farmer fields as compost. No other chemicals and micronutrients were used for whole process.

\section{Testing}

The working, performance of digester, volume of biogas, effects of temperature was tested in this research. The testing procedure continued for 3 months. The volume of biogas was measured daily in the morning with the help of gas flow meter. The effect of temperature was observed from variation in gas production. The effect of the weight of material and pressure of biogas inside and outside the digester was also observed on daily basis. The leakage in welded manhole on the top and biodigested slurry system was also observed.

\section{Solid Bio-digested slurry evacuating system (SBES)}

The pressure of biogas decreases as time passes which require refilling.

During testing process the same thing happened after three months, the pressure of biogas became very low which required refilling and PS was converted into solid bio digested slurry which needs to remove. For removal, a cone with manhole (3feet diameter) was designed at the bottom. By opening this, the SBES falls on the ground. Within 15-20 minutes the plant becomes empty. This system is shown in fig. 3

\section{Results and Discussion}

The developed plant was tested for 3 months, from May 2017-June 2017. The result for three months is given below in Table 2, 3 and 4 respectively which shows the day wise gas production and temperature variations. Further monthly gas production are compared and shown in graph.4.It was observed that rate of gas production decreases as time passes. Detailed result discussion is given in next section

\section{Results for biogas production}

In testing process, only paddy straw and cow dung were used without consumption of micronutrients or any other product for increasing the biogas production. The plant was entirely paddy straw based BP. 
After filling the plant with $450 \mathrm{~kg}$ of paddy straw with $150 \mathrm{~kg}$ cow dung it started producing biogas within 7 days. The purpose of mixing cow dung was to boost the anaerobic fermentation at the initial stage only. Further paddy straw has its own capacity and energy to produce biogas continuously for three months. In first month, for first fifteen days the BP was up to $11.421 \mathrm{~m}^{3}$ and for next 15 days $34.919 \mathrm{~m}^{3}$ of biogas was produced. It touched the mark of $3.002 \mathrm{~m}^{3}$ on 24.05 .2017 and 3.000 on 31.05.2017. From 27.05.2017 to 6.06 .2017 an average $2 \mathrm{~m}^{3}$ of biogas was produced. The data is shown in table 2. This change can also be observed in graph.1. Total $46.340 \mathrm{~m}^{3}$ biogas was produced.

In second month, above $1 \mathrm{~m}^{3}$ of biogas produced daily. An average of $1.311 \mathrm{~m}^{3}$ biogas produced in second month. The total biogas produced was $39.350 \mathrm{~m}^{3}$ as shown in table.3. Graph 2 represents the digester uniformly produced biogas.

In third month, it is clear from table 3 that BP started decreasing. The production was low and below $1 \mathrm{~m}^{3}$ for almost all days which is clear from graph 3 as well. An average of $0.673 \mathrm{~m}^{3}$ biogas was obtained in third month with total BP of $20.888 \mathrm{~m}^{3}$.

The total biogas produced in three months was $106.578 \mathrm{~m}^{3}$ which is equivalent to $3.23 \mathrm{LPG}$ cylinders, with average weight of $45.938 \mathrm{~kg}$. The produced biogas is enough for a normal family size of 5 .

\section{Effects of temperature}

For anaerobic fermentation the favorable temperature is above $25^{\circ} \mathrm{C}$. In this research it was observed that the temperature varied from $31^{\circ} \mathrm{C}$ to $45^{\circ} \mathrm{C}$, which was favorable to digester. During testing, the first month BP was high and little fall was observed in second month. In last month biogas production was drastically decreased as shown in graph 3 . The temperature variation was very minimal for all three months which made it clear that temperature had no effect in variation of biogas production, until and unless it works under favorable temperature conditions. The monthly decrease in BP is shown in graph 4 which clearly shows that the biogas production doesn't depend on temperature but upon the freshness, strength and energy of the feeder material. Further the reduction was observed after two months and during third month it stopped producing biogas. The bio energy was consumed by dry anaerobic fermentation in the absence of oxygen which made refilling mandatory.

\section{Results for solid bio-digested slurry evacuating system}

The total time taken for evacuating of $600 \mathrm{~kg}$ of solid bio-digested slurry was 20 minutes. The design made for the evacuating was feasible and successful as to remove or lift that big quantity of solid bio-digested waste was difficult. The system so made is easy to handle by a single person.

\section{Results for design \& fabricated mild steel plant}

A leakage proof system was designed and manufactured. During the testing of the plant there was no leakage problem observed as a leakage proof manhole was attached on the top. Solid bio-digested slurry removal system was designed in such a way that it can easily be handled by a single person. During the removal of slurry, it has been observed that it is easy to handle and feasible. SBDS removal system was placed three feet above the ground for easy handling and removal of material. The stand of three girders shows strength whole time and no problem was observed in it. 
Table.1 Compositionof feeding material

\begin{tabular}{|c|c|}
\hline Composition & $460 \mathrm{~kg}$ paddy straw crop residue. \\
+ & $150 \mathrm{~kg}$ cow dung. \\
\hline
\end{tabular}

Table.2 First month biogas production (May)

\begin{tabular}{|c|c|c|c|}
\hline S.No & Date & $\begin{array}{l}\text { Gas Production/day } \\
\left(\mathrm{m}^{3}\right)\end{array}$ & Temperature \\
\hline 1 & 09.05 .2017 & 1.4 & $38^{\circ} \mathrm{C}$ \\
\hline 2 & 10.05.2017 & 1.49 & $38^{\circ} \mathrm{C}$ \\
\hline 3 & 11.05 .2017 & 1.294 & $37^{\circ} \mathrm{C}$ \\
\hline 4 & 12.05 .2017 & 0.571 & $39^{\circ} \mathrm{C}$ \\
\hline 5 & 13.05 .2017 & 0.657 & $41^{\circ} \mathrm{C}$ \\
\hline 6 & 14.05 .2017 & 0.568 & $40^{\circ} \mathrm{C}$ \\
\hline 7 & 15.05 .2017 & 0.678 & $41^{\circ} \mathrm{C}$ \\
\hline 8 & 16.05 .2017 & 0.033 & $35^{\circ} \mathrm{C}$ \\
\hline 9 & 17.05.2017 & 0.566 & $35^{\circ} \mathrm{C}$ \\
\hline 10 & 18.05.2017 & 0.623 & $37^{\circ} \mathrm{C}$ \\
\hline 11 & 19.05.2017 & 0.471 & $31^{\circ} \mathrm{C}$ \\
\hline 12 & 20.05.2017 & 0.786 & $33^{\circ} \mathrm{C}$ \\
\hline 13 & 21.05.2017 & 0.897 & $32^{\circ} \mathrm{C}$ \\
\hline 14 & 22.05.2017 & 0.914 & $30^{\circ} \mathrm{C}$ \\
\hline 15 & 23.05.2017 & 0.473 & $30^{\circ} \mathrm{C}$ \\
\hline 16 & 24.05.2017 & 3.002 & $38^{\circ} \mathrm{C}$ \\
\hline 17 & 25.05.2017 & 1.792 & $38^{\circ} \mathrm{C}$ \\
\hline 18 & 26.05.2017 & 1.698 & $40^{\circ} \mathrm{C}$ \\
\hline 19 & 27.05.2017 & 2.453 & $41^{\circ} \mathrm{C}$ \\
\hline 20 & 28.05 .2017 & 2.234 & $39^{\circ} \mathrm{C}$ \\
\hline 21 & 29.05.2017 & 2.343 & $40^{\circ} \mathrm{C}$ \\
\hline 22 & 30.05 .2017 & 2.733 & $34^{\circ} \mathrm{C}$ \\
\hline 23 & 31.05 .2017 & 3.228 & $27^{\circ} \mathrm{C}$ \\
\hline 24 & 01.06.2017 & 2.853 & $35^{\circ} \mathrm{C}$ \\
\hline 25 & 02.06 .2017 & 1.99 & $40^{\circ} \mathrm{C}$ \\
\hline 26 & 03.06.2017 & 1.91 & $41^{\circ} \mathrm{C}$ \\
\hline 27 & 04.06 .2017 & 1.983 & $43^{\circ} \mathrm{C}$ \\
\hline 28 & 05.06.2017 & 1.896 & $39^{\circ} \mathrm{C}$ \\
\hline 29 & 06.06 .2017 & 2.026 & $40^{\circ} \mathrm{C}$ \\
\hline 30 & 07.06.2017 & 1.466 & $38^{\circ} \mathrm{C}$ \\
\hline \multirow[t]{2}{*}{31} & 08.06.2017 & 1.312 & $38^{\circ} \mathrm{C}$ \\
\hline & Total & $46.340 \mathrm{~m}^{3}$ & \\
\hline
\end{tabular}


Table.3 Second month biogas production (June)

\begin{tabular}{|c|c|c|c|}
\hline S.No & Date & $\begin{array}{l}\text { Gas Production/day } \\
\left(\mathrm{m}^{3}\right)\end{array}$ & Temperature \\
\hline 1 & 09.06 .2017 & 1.211 & $38^{\circ} \mathrm{C}$ \\
\hline 2 & 10.06.2017 & 1.302 & $37^{\circ} \mathrm{C}$ \\
\hline 3 & 11.06 .2017 & 1.232 & $34^{\circ} \mathrm{C}$ \\
\hline 4 & 12.06 .2017 & 1.542 & $34^{\circ} \mathrm{C}$ \\
\hline 5 & 13.06.2017 & 1.409 & $36^{\circ} \mathrm{C}$ \\
\hline 6 & 14.06 .2017 & 1.311 & $35^{\circ} \mathrm{C}$ \\
\hline 7 & 15.06 .2017 & 1.369 & $35^{\circ} \mathrm{C}$ \\
\hline 8 & 16.06 .2017 & 1.351 & $31^{\circ} \mathrm{C}$ \\
\hline 9 & 17.06.2017 & 1.674 & $37^{\circ} \mathrm{C}$ \\
\hline 10 & 18.06.2017 & 1.232 & $37^{\circ} \mathrm{C}$ \\
\hline 11 & 19.06.2017 & 1.453 & $35^{\circ} \mathrm{C}$ \\
\hline 12 & 20.06.2017 & 1.323 & $32^{\circ} \mathrm{C}$ \\
\hline 13 & 21.06.2017 & 1.273 & $28^{\circ} \mathrm{C}$ \\
\hline 14 & 22.06.2017 & 1.275 & $31^{\circ} \mathrm{C}$ \\
\hline 15 & 23.06 .2017 & 1.35 & $32^{\circ} \mathrm{C}$ \\
\hline 16 & 24.06.2017 & 1.518 & $35^{\circ} \mathrm{C}$ \\
\hline 17 & 25.06.2017 & 1.556 & $36^{\circ} \mathrm{C}$ \\
\hline 18 & 26.06.2017 & 1.769 & $32^{\circ} \mathrm{C}$ \\
\hline 19 & 27.06 .2017 & 1.518 & $37^{\circ} \mathrm{C}$ \\
\hline 20 & 28.06.2017 & 1.478 & $31^{\circ} \mathrm{C}$ \\
\hline 21 & 29.06.2017 & 1.159 & $27^{\circ} \mathrm{C}$ \\
\hline 22 & 30.06 .2017 & 1.023 & $33^{\circ} \mathrm{C}$ \\
\hline 23 & 01.07.2017 & 1.123 & $34^{\circ} \mathrm{C}$ \\
\hline 24 & 02.07.2017 & 1.213 & $33^{\circ} \mathrm{C}$ \\
\hline 25 & 03.07.2017 & 1.096 & $35^{\circ} \mathrm{C}$ \\
\hline 26 & 04.07.2017 & 1.145 & $30^{\circ} \mathrm{C}$ \\
\hline 27 & 05.07.2017 & 1.113 & $36^{\circ} \mathrm{C}$ \\
\hline 28 & 06.07.2017 & 1.014 & $32^{\circ} \mathrm{C}$ \\
\hline 29 & 07.07.2017 & 1.214 & $32^{\circ} \mathrm{C}$ \\
\hline \multirow[t]{2}{*}{30} & 08.07.2017 & 1.104 & $35^{\circ} \mathrm{C}$ \\
\hline & Total & $39.350 \mathrm{~m}^{3}$ & \\
\hline
\end{tabular}


Table.4 Second month biogas production (July)

\begin{tabular}{|c|c|c|c|}
\hline S.No & Date & $\begin{array}{l}\text { Biogas Production/day } \\
\left(\mathrm{m}^{3}\right)\end{array}$ & Temperature \\
\hline 1 & 09.07.2017 & 1.11 & $37^{\circ} \mathrm{C}$ \\
\hline 2 & 10.07.2017 & 1.107 & $37^{\circ} \mathrm{C}$ \\
\hline 3 & 11.07 .2017 & 1.001 & $33^{\circ} \mathrm{C}$ \\
\hline 4 & 12.07.2017 & 1.101 & $29^{\circ} \mathrm{C}$ \\
\hline 5 & 13.07.2017 & 0.848 & $36^{\circ} \mathrm{C}$ \\
\hline 6 & 14.07.2017 & 0.89 & $33^{\circ} \mathrm{C}$ \\
\hline 7 & 15.07.2017 & 0.968 & $34^{\circ} \mathrm{C}$ \\
\hline 8 & 16.07.2017 & 0.871 & $34^{\circ} \mathrm{C}$ \\
\hline 9 & 17.07.2017 & 0.905 & $31^{\circ} \mathrm{C}$ \\
\hline 10 & 18.07.2017 & 0.86 & $35^{\circ} \mathrm{C}$ \\
\hline 11 & 19.07.2017 & 0.784 & $36^{\circ} \mathrm{C}$ \\
\hline 12 & 20.07.2017 & 0.656 & $31^{\circ} \mathrm{C}$ \\
\hline 13 & 21.07 .2017 & 0.678 & $33^{\circ} \mathrm{C}$ \\
\hline 14 & 22.07.2017 & 0.59 & $34^{\circ} \mathrm{C}$ \\
\hline 15 & 23.07.2017 & 0.654 & $32^{\circ} \mathrm{C}$ \\
\hline 16 & 24.07.2017 & 0.567 & $35^{\circ} \mathrm{C}$ \\
\hline 17 & 25.07.2017 & 0.684 & $32^{\circ} \mathrm{C}$ \\
\hline 18 & 26.07.2017 & 0.512 & $33^{\circ} \mathrm{C}$ \\
\hline 19 & 27.07.2017 & 0.589 & $30^{\circ} \mathrm{C}$ \\
\hline 20 & 28.07.2017 & 0.527 & $34^{\circ} \mathrm{C}$ \\
\hline 21 & 29.07.2017 & 0.509 & $33^{\circ} \mathrm{C}$ \\
\hline 22 & 30.07 .2017 & 0.48 & $34^{\circ} \mathrm{C}$ \\
\hline 23 & 31.07 .2017 & 0.456 & $30^{\circ} \mathrm{C}$ \\
\hline 24 & 01.08 .2017 & 0.46 & $32^{\circ} \mathrm{C}$ \\
\hline 25 & 02.08 .2017 & 0.561 & $31^{\circ} \mathrm{C}$ \\
\hline 26 & 03.08.2017 & 0.41 & $31^{\circ} \mathrm{C}$ \\
\hline 27 & 04.08 .2017 & 0.455 & $35^{\circ} \mathrm{C}$ \\
\hline 28 & 05.08.2017 & 0.355 & $33^{\circ} \mathrm{C}$ \\
\hline 29 & 06.08 .2017 & 0.364 & $34^{\circ} \mathrm{C}$ \\
\hline \multirow{3}{*}{30} & 07.08.2017 & 0.375 & $34^{\circ} \mathrm{C}$ \\
\hline & 08.08.2017 & 0.561 & $34^{\circ} \mathrm{C}$ \\
\hline & & Total & $20.888 m^{3}$ \\
\hline
\end{tabular}


Fig.1 Drawing of Paddy straw based mild steel biogas plant

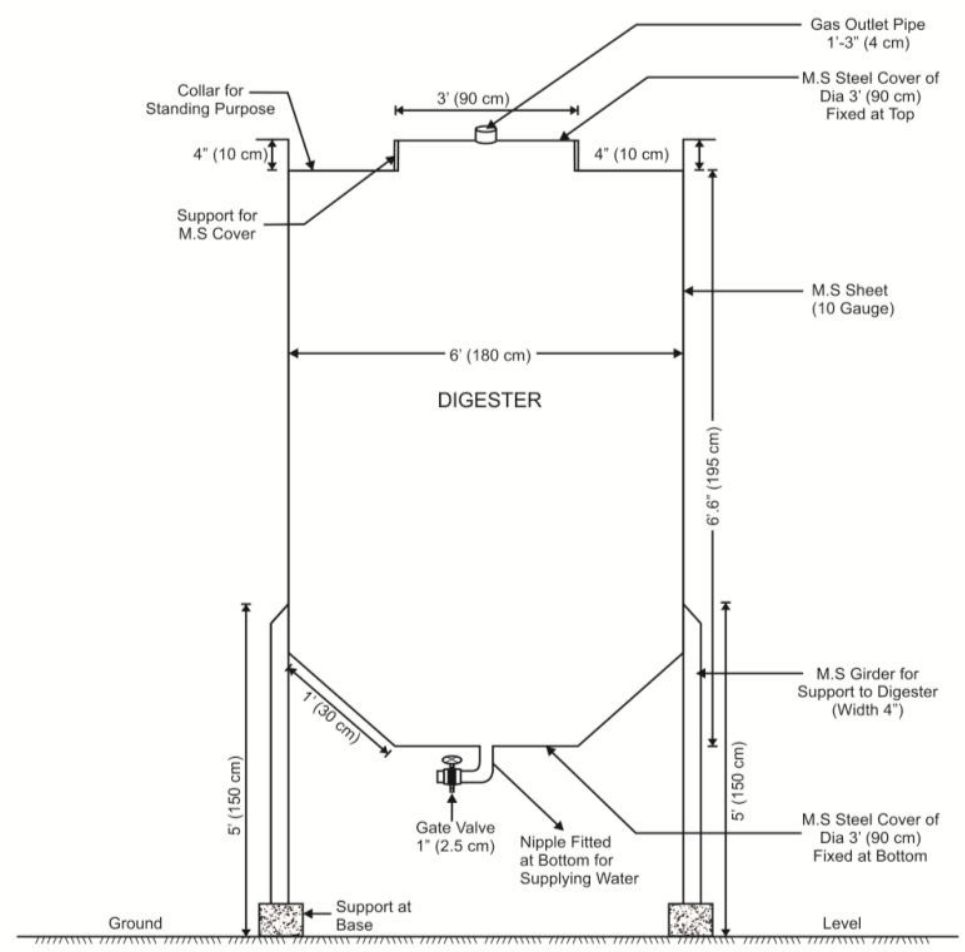

Fig.2 Paddy straw based mild steel biogas plant (after fabrication)

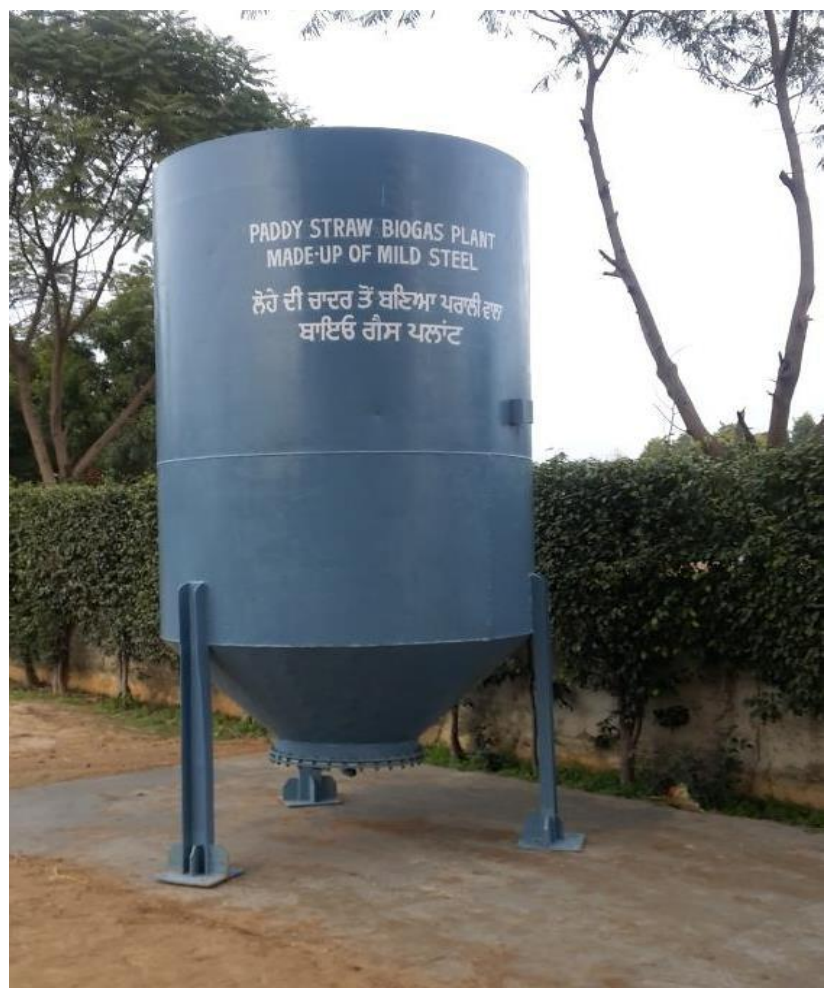


Fig.3 Slurry removal system attached with a cone at the bottom of the plant

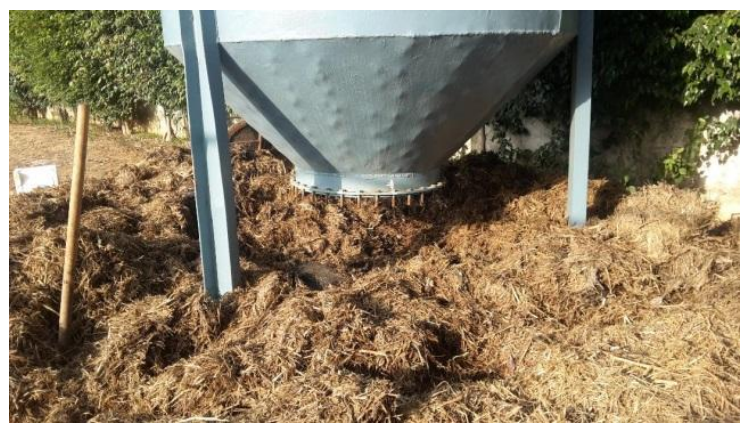

Graph.1 Biogas production for first month (May)

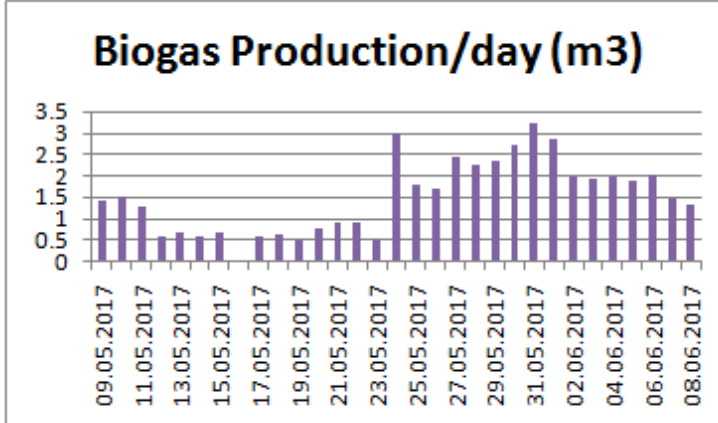

Graph.3 Biogas production for Third month (July)

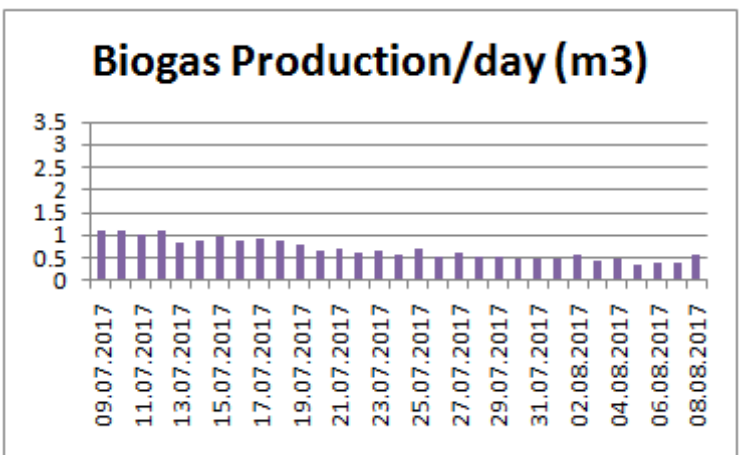

Graph.2 Biogas production for second month (June)

\section{Biogas Production/day (m3)}

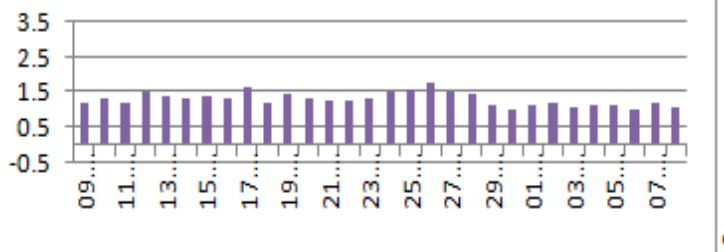

Graph.4 comparison of Monthly Biogas production

\section{Gas Production/Month (m3)}

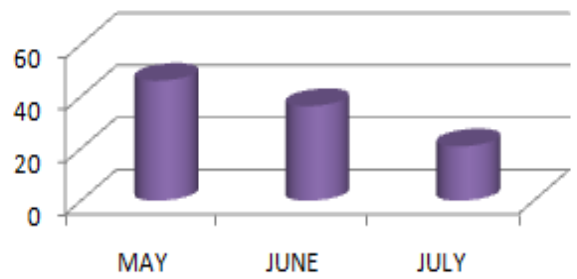


No vibrations or chattering occurred during the working.

The coating of metallic smoke grey paint was provided to inner and outer wall of the plant to avoid rusting. Gate valves were inserted on the top of covers for continuous flow of biogas.

The plant shape is cylindrical and no bursting due to biogas was observed.

From the research following points are concluded.

Summer season is very favorable for developed digester and in India favorable conditions remain for 8 months. In winter season insulation is required. By constructing dry fermentation paddy straw based biogas plants with alternate construction material like M.S. sheet/fiber in place of brick masonry, the cost of the plant can be reduced and also the operation of the plant is easy with these efforts, this technology has to be feasible at the individual level.

The biogas produced is enough for family usage. As it produces 3.23 LPG cylinders and which are sufficient for Indian family size of 5. Removal of huge amount of solid biodigested slurry is easy.

The design is suitable for family and no accidental chances arise during the trails.

This design is eco-friendly as it overcomes the air pollution problem raised due to paddy straw.

This is a technical and useful concept for paddy straw management.

\section{Future scope}

The digester size can be increased up to $100 \mathrm{~m}^{3}$ for major production of biogas.
Paddy straw can be utilized for power generation.

The major projects can produce cooking gas for the whole village.

The solid bio-digested slurry produced from the plant can be utilized in farmer fields, and sold in the market.

\section{Acknowledgment}

This research is funded by Punjab agricultural university.

\section{References}

1. Angelis- A. Dimakis, M. Biberacher, J. Dominguez, G.Fiorese, S. Gadocha, Gnansounou, G. Guariso, Methods and tools to evaluate the availability of renewable energy resources, Renewable Sustainable EEnergy Rev.15(2011) p1182-1200.

2. Apte, A., V. Cheernam, M. Kamat, S. Kamat, P. Kashikar, and H. Jeswani, Potential of Using Kitchen Waste in a Biogas Plant International Journal of Environmental Science and Development, Vol. 4, No. 4, August 2013.

3. Chandra, R., Takeuchi, H., Hasegawa, T., \& Kumar, R. (2012).Improving biodegradability and biogas production of wheat straw substrates using sodium hydroxide and hydrothermalpretreatments. Energy, 43(1), 273-82.

4. doi:10.1016/j.energy.2012.04.029.

5. Farhiya Puspita sari,Budiyona,Enhanced biogas production from rice straw with various pretreatment-A Review Waste technology:An international journal vol 2 (2014) p17-25

6. Franco Cotana, Alessandro Petrozzi, Gianluca Cavalaglio,Valentina Coccia, Anna Laura Pisello, and Emanuele 
Bonamente, A batch digester plant for biogas production and energy enhancement of organic residues from collective activities, Available online at www.sciencedirect.com, Energy Procedia 61 (2014) 1669 - 1672.

7. Grewal NS, Ahluwalia S and Brar G Handbook of Biogas Technology Published in Punjab Agricultural University, Ludhiana 1-106

8. Guohua Shi,Cost Optimal Selection of Storage Tanks in LPG Vaporization Station Natural Resources, 2012, Vol.3, p164-169, September 2012.

9. Guohua Shi,Cost

Optimal Selection of Storage Tanks in LPG Vaporization Station Natural Resources, 2012, Vol.3, p164-169, September 2012.

10. Harmanjot Kaur, Vipan Kumar Sohpal and Sachin Kumar,Designing of Small Scale Fixed Dome Biogas Digester For Paddy Straw, International Journal of Renewable Energy Research, Vol.7,No.1,2017.

11. Jewell, W J, R.M.Kabrick, S orto Dell, K $\mathrm{J}$ Fanfoni Low cost approach to methane generation,storage and utilization from crop residue and animal residues. Presented at American Institte of Chemical Engineers Symposium "Biotechnology in Energy Production "Chicago Illinois 1-22 (2000)

12. Lansing, S.; Martin, J.F.; Botero, R.B.; da Silva, T.N.; da Silva, E.D, (2010),
Methane production in low-cost, unheated, plug-flow digesters treating swine manure and used cooking grease. Bioresour. Technol, 101, 4362-4370.

13. Lohith, M C Math, Design, Development and performance Evaluation of Biogas Digester Filed with Multiple Feed stocks. IJIRSET,Vol.5,p14753-14759,2016

14. M.Samer, Biogas Plant Constructions, Cairo University, Faculty of Agriculture, Department of Agricultural Engineering, Egypt.

15. Madhuri Narra, Velmurugan Balasubramanian, Anil Kurchania, Bhim Sen Pathak, Murari Shyam Enhanced biogas production from rice straw by selective micronutrients under solid state anaerobic digestion,Bioresource Technology 220(2016) 666-671.

16. Nicolae Scarlat, Jean-François Dallemand, Fernando Fahl Biogas: Developments and perspectives in Europe, Renewable Energy, 129(2018) p 457-472.

17. Rathod, V.P, P.V. Bhale, R.S.Mehta,K.Harmani, S.Bilimoria, A.Mahida,H.Champaneri, Biogas Production from Water Hyacinth in the Batch type Anaerobic Digester, Materials Today: Proceedings 5 (2018) 2334623350.

18. Singh, R.B., R.C. Sana, Mahendra Singh, Dinesh Chandra, S.G. Shukla, T.K.Walli, P.K.Pradhan and H.P.Kessels, Rice Straw-Its Production and Utilization in India.

\section{How to cite this article:}

Jasvarinder Chalotra and Sarbjit Singh Sooch. 2020. Development and Optimization of Mild Steel Biogas Plant for utilising Paddy Straw Residue. Int.J.Curr.Microbiol.App.Sci. 9(01): 2532-2543. doi: https://doi.org/10.20546/ijcmas.2020.901.288 